\title{
Correction to: In Vitro Evaluation of the Apoptotic, Autophagic, and Necrotic Molecular Pathways of Fluoride
}

\author{
F. Urut ${ }^{1} \cdot$ S. Dede ${ }^{1} \cdot$ V. Yuksek ${ }^{2} \cdot$ S. Cetin ${ }^{1} \cdot$ A. Usta ${ }^{3} \cdot$ M. Taspinar ${ }^{4}$
}

Published online: 11 May 2021

(C) Springer Science+Business Media, LLC, part of Springer Nature 2020

\section{Correction to: Biological Trace Element Research. https://doi.org/10.1007/s12011-020-02491-3}

The original version of this article unfortunately contained mistakes. The complete list of corrections is given below.

- The author's affiliations in now corrected in the author group.

- The correct order of the keywords should be: Apoptosis, Autophagy, In vitro, Naf, Necrosis, NRK-52E cell line

- $p .2$, fourth sentence of the last paragraph under the header "Total RNA Isolation and Quantitative Real-Time PCR", BCt should be CT
- p.3, second sentence of the first paragraph under the Results section, results should be PCR results

- The correct bibliographic information for reference [1] should be Yur F, Mert N, Dede S, Değer Y, Ertekin A, Mert H, Yaşar S, Doğan I, Işık A (2013) Evaluation of serum lipid fractions and tissue antioxidant levels in sheep with fluorosis. Fluoride 46(2):90-96

The original article has been corrected.

Publisher's Note Springer Nature remains neutral with regard to jurisdictional claims in published maps and institutional affiliations.

The online version of the original article can be found at https://oi.org/ 10.1007/s12011-020-02491-3

\footnotetext{
S. Dede

sdede@yyu.edu.tr

1 Biochemistry Department, Faculty of Veterinary Medicine, Van Yuzuncu Yil University, 65090 Van, Turkey

2 Özalp Regional High School, Van Yuzuncu Yil University, 65090 Van, Turkey

3 Chemistry Department, Science Faculty, Van Yuzuncu Yil University, 65090 Van, Turkey

4 Medical Biology Department, Medical Faculty, Aksaray University, Aksaray, Turkey
} 